\title{
Beta-cell function improved by supplementing basal insulin secretion in mild diabetes
}

\author{
R C TURNER, S T MCCARTHY, R R HOLMAN, E HARRIS
}

British Medical fournal, 1976, 1, 1252-1254

\begin{abstract}
Summary
Insulin supplements, predominantly as a constant basal fish insulin infusion, were given to patients with mild diabetes to reduce the overnight fasting glucose level to normal. The basal plasma human insulin levels were reduced to subnormal levels by the infusion, and the insulin response to intravenous glucose was enhanced. The $\beta$-cell in diabetes seems to be in a vicious circle in which an impaired insulin response to glucose produces hyperglycaemia, which stresses $\beta$-cell function, making it more inefficient. A constant basal insulin supplement to induce basal normoglycaemia may benefit $\beta$-cell function in diabetes.
\end{abstract}

\section{Introduction}

An increased overnight fasting plasma glucose level is the predominant plasma glucose abnormality of mild diabetes, the glucose response to a meal being less abnormal. ${ }^{1}$ The raised basal plasma glucose is associated with, and is probably due to, a decreased insulin response to glucose, ${ }^{1-3}$ whereas the insulin response to a meal is less impaired. ${ }^{1} \mathrm{~A}$ logical conclusion is that replacement insulin treatment in diabetes should primarily supplement the basal insulin secretion to lower the basal plasma glucose to normal.

Diabetics with a raised basal plasma glucose level have a considerably impaired insulin response to glucose. ${ }^{4} \beta$-Cell function in diabetes may be stressed by the hyperglycaemia. We have induced normal overnight fasting plasma glucose levels in patients with mild diabetes with a constant intravenous infusion of fish insulin. The endogenous plasma human insulin levels were then assayed using a specific antiserum. ${ }^{5}$

\section{Methods}

Seven non-obese diabetic men aged 45-63 years who had been treated only with an energy-restricted, $40 \%$ carbohydrate diet were studied. All were symptomless and had no glycosuria. They were admitted to hospital for six days for the investigation, during which time they were kept on their usual diet and were ambulant during the day. On the second and fifth day they were given a standard breakfast ${ }^{1}$ as previously described except that the milk consisted of $25 \mathrm{~g}$ Marvel powdered skimmed milk and $12 \mathrm{~g}$ powdered egg white made up to $300 \mathrm{ml}$ with water. Two basal blood samples were taken 10 minutes apart, and after breakfast samples were taken every 10 minutes for 90 minutes and then every 30 minutes up to 180 minutes. On the third and sixth day they underwent an intravenous glucose tolerance test $(0 \cdot 1 \mathrm{~g} / \mathrm{kg}$ intravenous glucose over two minutes with samples $3,4,5$, $6,10,15,20,25$, and 30 minutes after the beginning of the infusion).

Nuffield Department of Clinical Medicine, Radcliffe Infirmary, Oxford OX2 6HE

R C TURNER, MD, MRCP, medical tutor and honorary consultant physician $S$ T MCCARTHY, MRCP, senior registrar (now consultant geriatrician)

R R HOLMAN, MB, CHB, research fellow

E HARRIS, BSC, research assistant
Ninety minutes after the glucose infusion an insulin tolerance test was performed $(0.025 \mathrm{U} / \mathrm{kg}$ monocomponent pork insulin (Novo) after two initial blood samples with subsequent samples at $20,25,30,35$, and 40 minutes). Blood samples were taken via a Teflon intravenous catheter (Dannula) inserted in the antecubital fossa or forearm.

After the test on the third day the patients were started on a constant fish insulin infusion given via a $61 \mathrm{~cm}(24 \mathrm{in})$ intravenous catheter (Intracath) inserted into a median antecubital vein. After lunch the plasma glucose level was lowered to about $5.5 \mathrm{mmol} / 1(100 \mathrm{mg} / 100 \mathrm{ml})$ by intravenous boluses of pork Actrapid monocomponent insulin, and the fish insulin infusion was then adjusted during the afternoon with a Precidor variable pump to maintain the basal plasma glucose at $4.4 \mathrm{mmol}_{\text {/ }}(80 \mathrm{mg} / 100 \mathrm{ml})$. The thus determined basal fish insulin supplement was then continued from a portable clockwork Handley pump, and little change in the rate of insulin infusion was needed. The infusion was stopped immediately before the intravenous insulin test on the sixth day. The four patients with more severe diabetes were given extra supplements of insulin before main meals to help attain normoglycaemia more rapidly.

Plasma human insulin was measured ${ }^{6}$ using a human insulin standard (Novo) and a discriminating antiserum, GP5 (Dr C Lowy). ${ }^{5}$ The first-phase insulin response to intravenous glucose was measured as the $0-10$ minute incremental area above the mean of the two basal samples. Plasma glucose was measured using glucose oxidase and an oxygen electrode (Analox Instruments). The ideal weights were obtained from Metropolitan Life Tables. ${ }^{7}$ Statistical differences were calculated using Student's paired $t$ test and correlation coefficients by least square analysis. Glucose and insulin areas were calculated using linear interpolation between assay results.

\section{Results}

The table summarises the results. The height of the pretreatment basal plasma glucose level correlated with the dose of the basal insulin supplement required to obtain a normal basal plasma glucose $(\mathbf{r}=$ $0.90 ; \mathbf{P}<0.01$ ). After the insulin supplements the basal plasma human insulin was reduced $(P<0.005)$.

The rise in plasma glucose after intravenous glucose was similar before the insulin infusion and 64 hours after the insulin infusion (mean $\pm 1 \mathrm{SD}$ ) $3 \cdot 0 \pm 1 \cdot 4$ and $3 \cdot 6 \pm 1 \cdot 1 \mathrm{mmol} / 1(54 \pm 25$ and $65 \pm 20$ $\mathrm{mg} / 100 \mathrm{ml}$ ) respectively five minutes after beginning of glucose

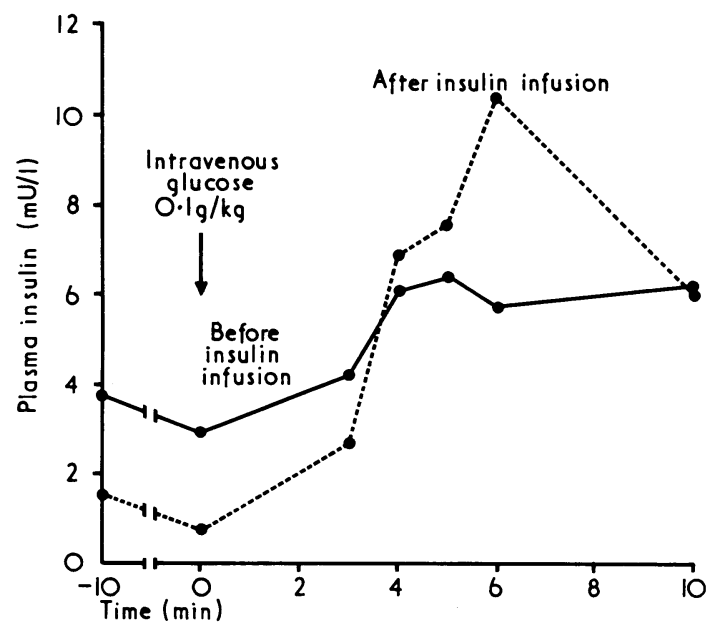

FIG 1-Mean plasma human insulin concentration before and after 64 hours of insulin supplements, including first-phase insulin response to $0.1 \mathrm{~g} / \mathrm{kg}$ intravenous glucose. 
Patients' weights and glucose and insulin values before and during fish insulin infusion, and details of insulin treatment

\begin{tabular}{|c|c|c|c|c|c|c|c|c|c|c|c|c|}
\hline \multirow[t]{2}{*}{$\begin{array}{l}\text { Case } \\
\text { No }\end{array}$} & \multirow[t]{2}{*}{$\underset{(\mathrm{kg})}{\text { Weight }}$} & \multirow[t]{2}{*}{$\begin{array}{c}\text { Ideal } \\
\text { weight } \\
\left(\begin{array}{l}0 \\
0\end{array}\right)\end{array}$} & \multicolumn{2}{|c|}{$\begin{array}{c}\text { Mean basal } \\
\text { plasma glucose } \\
(\mathrm{mmol} / \mathrm{l})\end{array}$} & \multicolumn{2}{|c|}{$\begin{array}{c}\text { Mean basal } \\
\text { plasma insulin } \\
(\mathrm{mU} / \mathbf{l})\end{array}$} & \multicolumn{2}{|c|}{$\begin{array}{l}\text { First-phase insulin } \\
\text { response to IV } \\
\text { glucose } 0-10 \mathrm{~min} \\
\text { incremental area } \\
\text { (mU } 1 . \mathrm{min})\end{array}$} & \multicolumn{2}{|c|}{$\begin{array}{l}\text { Breakfast } \\
\text { total } 0-180 \mathrm{~min} \\
\text { glucose area } \\
(\mathrm{mmol} \text { l.min) }\end{array}$} & \multirow[t]{2}{*}{$\begin{array}{l}\text { Basal insulin } \\
\text { supplements } \\
\text { (U/day) }\end{array}$} & \multirow[t]{2}{*}{$\begin{array}{c}\text { Route of } \\
\text { pre-meal } \\
\text { supplements }\end{array}$} \\
\hline & & & Before & During & Before & During & Before & During & Before & During & & \\
\hline $\begin{array}{l}1 \\
2 \\
3 * \\
4 \\
5 \\
6 \\
7\end{array}$ & $\begin{array}{l}79 \\
71 \\
65 \\
80 \\
75 \\
61 \\
78\end{array}$ & $\begin{array}{l}+13 \\
-1 \\
-3 \\
+12 \\
+7 \\
-2 \\
+10\end{array}$ & $\begin{array}{r}6 \cdot 0 \\
5.7 \\
7.3 \\
7 \cdot 8 \\
12 \cdot 2 \\
5.4 \\
7 \cdot 1\end{array}$ & $\begin{array}{l}4 \cdot 3 \\
4 \cdot 2 \\
4 \cdot 3 \\
2 \cdot 7 \\
4 \cdot 2 \\
4 \cdot 4 \\
4 \cdot 5\end{array}$ & $\begin{array}{l}4 \cdot 8 \\
3 \cdot 5 \\
5 \cdot 9 \\
3 \cdot 4 \\
2.9 \\
2 \cdot 0 \\
5 \cdot 7\end{array}$ & $\begin{array}{l}2 \cdot 8 \\
1 \cdot 0 \\
2 \cdot 5 \\
1.5 \\
2 \cdot 1 \\
1 \cdot 2 \\
1 \cdot 2\end{array}$ & $\begin{array}{r}25 \cdot 3 \\
24 \cdot 1 \\
18 \cdot 6 \\
3.4 \\
8 \cdot 8 \\
21.6 \\
15.6\end{array}$ & $\begin{array}{l}46 \cdot 9 \\
45 \cdot 9 \\
12 \cdot 2 \\
12 \cdot 4 \\
29 \cdot 2 \\
54 \cdot 0 \\
80 \cdot 6\end{array}$ & $\begin{array}{l}1333 \\
1097 \\
1320 \\
1773 \\
2556 \\
1446 \\
1872\end{array}$ & $\begin{array}{l}1043 \\
1149 \\
1261 \\
1380 \\
1304 \\
1615 \\
1523\end{array}$ & $\begin{array}{l}16 \\
12 \\
14 \\
22 \\
34 \\
14 \\
26\end{array}$ & $\begin{array}{c}\text { Subcutanous } \\
\text { Intravenous } \\
\text { " }\end{array}$ \\
\hline Mean $\pm 1 \mathrm{SD}$ & $73 \pm 7$ & $+5 \pm 7$ & $7 \cdot 3=2 \cdot 3$ & $4 \cdot 1=0.6$ & $4 \cdot 0 \pm 1 \cdot 5$ & $1.8 \pm 0.7$ & $16 \cdot 8=8 \cdot 1$ & $40 \cdot 2 \pm 24 \cdot 4$ & $1629 \div 489$ & $1325 \pm 200$ & $20 \pm 8$ & \\
\hline \multicolumn{2}{|c|}{ Significance of paired $t$ test } & & \multicolumn{2}{|c|}{$P<0.02$} & \multicolumn{2}{|c|}{$P<0.005$} & \multicolumn{2}{|c|}{$P<0.05$} & \multicolumn{2}{|c|}{$\mathrm{P}<0.2$} & & \\
\hline
\end{tabular}

*The first-phase insulin response did not improve in this patient; in the second test, blood samples were haemolysed, which might have caused spuriously low insulin values.

Conversion: SI to traditional units-Glucose: $1 \mathrm{mmol} / 1 \approx 18 \mathrm{mg} / 100 \mathrm{ml}$.

infusion. There was an increased first-phase incremental insulin response from 17 to $40 \mathrm{mU} / 1 . \mathrm{min}(\mathrm{P}<0.05)$ (fig 1). This compares with a response of $220 \pm 94 \mathrm{mU} / \mathrm{l} \cdot \mathrm{min}$ to the same glucose load in six normal subjects. The intravenous glucose tolerance, as measured by the incremental plasma glucose at 30 minutes, was slightly improved $(1.5 \pm 0.7$ and $1.2 \pm 0.7 \mathrm{mmol} / \mathrm{l}(27 \pm 13$ and $22 \pm 13 \mathrm{mg} / 100 \mathrm{ml})$; $\mathrm{P}<0 \cdot 1)$.

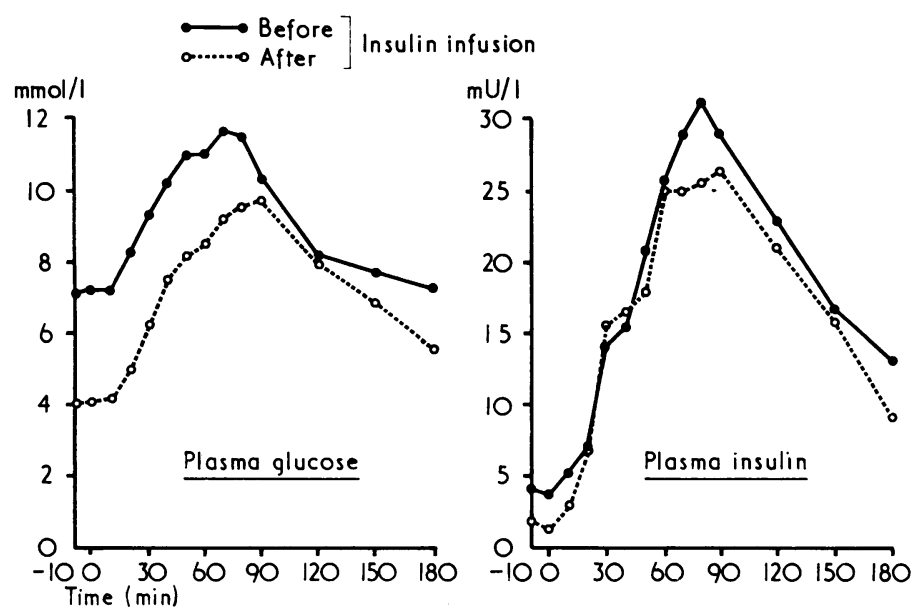

FIG 2-Mean plasma glucose and insulin concentration before and after 40 hours of insulin supplements in response to standard breakfast.

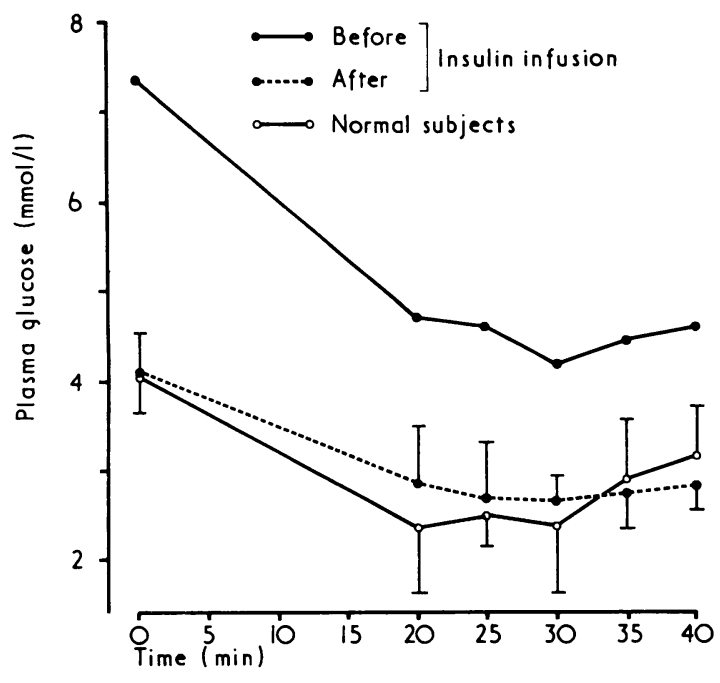

FIG 3-Mean ( $\pm 1 \mathrm{SD}$ ) plasma glucose concentrations after $0.025 \mathrm{U} / \mathrm{kg}$ intravenous insulin before and after 65 hours of insulin supplements in seven diabetic subjects and in control group of 11 non-obese males.
In response to the standard breakfast the incremental plasma glucose 0-180 minute area was increased after 40 hours of insulin infusion $(0-180$ minute area mean 303 and $583 \mathrm{mmol} / \mathrm{l} \cdot \mathrm{min}(5460$ and 10505 $\mathrm{mg} / 100 \mathrm{ml} . \mathrm{min}$ ) respectively; $\mathrm{P}<0.02)$. Nevertheless, in patients with a pretreatment basal plasma glucose over $5.8 \mathrm{mmol} / 1(105 \mathrm{mg} / 100 \mathrm{ml})$ the total glucose area was reduced in proportion to the degree of basal hyperglycaemia (fig 2 and table). The insulin response to the standard breakfast remained essentially unchanged even though the total glycaemic stimulus was less (mean 30-minute plasma insulin increment increased from 10 to $13 \mathrm{mU} / \mathrm{l}$, normal range $10-116 \mathrm{mU} / \mathrm{l}$ ).

When the basal plasma glucose concentration of the diabetics was reduced to normal by the insulin supplements the insulin sensitivity, as measured by the plasma glucose response to intravenous insulin, was very similar to that found in 11 normal weight men aged 30-45 given the same dose of intravenous insulin 90 minutes after a glucose load (fig 3).

\section{Discussion}

In response to lowering the overnight fasting, or basal, plasma glucose to normal there was a considerable reduction in the basal plasma insulin, and presumably in insulin secretion. Exogenous insulin in the dose given is unlikely to have a direct effect on insulin secretion, ${ }^{8}$ and the low plasma insulin associated with normal basal plasma glucose levels is further evidence that insulin deficiency is the predominant abnormality of maturity onset diabetes. The hypoglycaemic response to insulin in the diabetics after normoglycaemia had been established was similar to that in normal subjects. This does not support the suggestion that insulin resistance is a feature of mild diabetes. ${ }^{9}$

$\beta$-Cells are normally most responsive to changes in plasma glucose levels at the normal fasting glucose concentration..$^{10-12}$ In diabetes in man there is a decreased insulin secretory capacity to glucose. ${ }^{412}$ In the present study the first-phase insulin response to intravenous glucose was improved after restoration of normoglycaemia. The $\beta$-cells seemed to be "rested" by decreasing the glucose load, which allowed a store of readily available insulin to be accumulated. Thus in diabetes the $\beta$-cells are in a vicious circle in which the reduced insulin response to glucose leads to

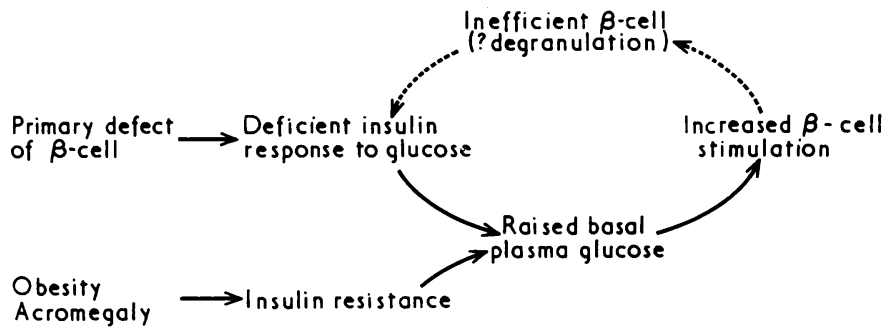

FIG 4-Postulated interaction between impaired insulin secretion of diabetes and basal plasma glucose concentration. 
hyperglycaemia, which deleteriously stresses their function (fig 4). Partial return of impaired insulin secretion has been noted after treatment of acute episodes of hyperglycaemia, ${ }^{13}$ but our results suggest that decreasing even slightly raised plasma glucose levels improves the efficiency of insulin secretion.

A constant basal insulin supplement in patients with mild diabetes reduces the basal plasma glucose concentration to normal. This allows the $\beta$-cell to function more efficiently, although it is unlikely that a completely normal response can be obtained. The total plasma glucose area after the standard breakfast was improved in proportion to the degree of basal hyperglycaemia when the fasting plasma glucose was over $5.8 \mathrm{mmol} / 1(105 \mathrm{mg} / 100 \mathrm{ml})$. The incremental plasma glucose response was increased and this may be secondary to the decreased overnight portal vein insulin concentration, allowing enhanced hepatic glucose efflux.

In rats prolonged hyperglycaemia causes degranulation of the $\beta$-cells ${ }^{14}$ and this may occur in diabetes in man. Chronic hyperglycaemia in cats sometimes induces permanent diabetes. ${ }^{15}$ It has been suggested that prolonged hyperglycaemia could irrevocably "exhaust" the islets and that improved treatment with insulin may prevent this. ${ }^{16}$ If dogs are treated with insulin to prevent hyperglycaemia induced by anterior pituitary extracts insulin depletion of the pancreas can be prevented. ${ }^{17}$

Attainment of normoglycaemia is usually the aim in the treatment of diabetes as the long-term complications are likely to be secondary to disturbed metabolism. We have shown that normoglycaemia also helps 3 -cell function. Basal insulin supplements allow correction of the raised basal plasma glucose of diabetes with minimal risk of hypoglycaemia. They could be provided by injection of a very long-acting insulin, and this simple form of insulin replacement treatment might be beneficial in patients with mild diabetes.

We thank Dr T D R Hockaday and Professor D J Weatherall for allowing us to study patients under their care and for their support; Miss P Harding and Mrs C Uren for their help; and the Oxford Regional Health Authority (Teaching) and the British Diabetes Association for grants.

\section{References}

1 Turner, R C, et al, submitted for publication.

2 Turner, R C, Harris, E, and Uren, C, submitted for publication.

3 McCarthy, S, Harris, E, and Turner, R C, submitted for publication.

4 Lerner, R L, and Porte, D, fournal of Clinical Investigation, 1972, 51, 1624

5 Turner, R C, and Johnson, P C, Lancet, 1973, 1, 1483.

${ }^{6}$ Albano, J D M, et al, Acta Endocrinologica, 1972, 70, 487.

7 Statistical Bulletin, Metropolitan Life Insurance Company, 1959, 40, November-December.

' Sando, H, Kanazawa, Y, and Kuzuya, T, American fournal of Physiology, 1970, 218, 1357.

${ }^{9}$ Shen, S, Reaven, R, and Farqhuar, T V, fournal of Clinical Investigation, $1970,49,2151$.

${ }^{10}$ Lerner, R L, and Porte, D, fournal of Clinical Investigation, 1971, 33, 409.

11 Pelkonen, R, Taskinen, M, and Nikkilä, E A, fournal of Clinical Endocrinology and Metabolism, 1974, 39, 418.

12 Turner, R C, et al, submitted for publication

${ }^{13}$ Foucar, E, and Field, J B, fournal of Clinical Endocrinology and Metabolism, 1972, 35, 288.

14 Carpenter, A M, and Lazarow, A, Diabetes, 1967, 16, 493

15 Dohan, F C, and Lukens, F D W, Endocrinology, 1948, 42, 244.

${ }^{16}$ Haist, R E, Campbell, J, and Best, C H, New England fournal of Medicine, 1940, 223, 607 .

17 Campbell, J, et al, American fournal of Physiology, 1940, 129, 328.

\title{
Effect of triamterene on leucocyte sodium and potassium levels in heart disease
}

\author{
E K DONALDSON, J PATRICK，S SIVAPRAGASM， M O WOO MING， G A O ALLEYNE
}

British Medical fournal, 1976, 1, 1254-1255

\section{Summary}

Sodium and potassium levels in plasma and leucocytes and the sodium efflux rate constants of leucocytes were measured in patients with congenital heart disease not on treatment, patients with valvular heart disease being treated with digoxin and conventional diuretics, and patients with valvular heart disease receiving digoxin and either conventional diuretics or triamterene or both. The group being treated with digoxin and conventional diuretics showed low cellular potassium levels, low sodium efflux rate constants, and a rise in cellular sodium levels. Patients given triamterene showed a rise in potassium levels in plasma and cells and in the sodium efflux rate constant.

University of the West Indies, Kingston 7, Jamaica

E K DONALDSON, MB, BS, research fellow, department of medicine

J PATRICK, MB, MRCP, research fellow, tropical metabolism research unit, and honorary consultant physician

S SIVAPRAGASM, MB, FFARCS, senior lecturer in anaesthetics

$M$ O WOO MING, FRCS, reader in surgery

G A O ALLEYNE, MD, FRCP, professor of medicine

\section{Introduction}

Heart failure is associated with abnormalities of intracellular electrolytes, total exchangeable potassium, and whole-body potassium. ${ }^{1-4}$ Diuretics and cardiac glycosides are only two of the factors that may affect intracellular electrolytes in heart failure. Much emphasis has been placed on the role of conventional diuretics in producing potassium depletion, but they do not appear to cause a significant reduction in whole-body or leucocyte potassium when used in accepted doses. ${ }^{35}$ Cardiac glycosides, however, interfere with potassium and sodium homoestasis at the cellular level. Ouabain inhibits the active component of sodium efflux in both red cells ${ }^{6}$ and leucocytes, ? causing a fall in intracellular potassium and a rise in intracellular sodium. It also reduces myocardial potassium. ${ }^{8}$ Acetylstrophanthin increases potassium outflow in the coronary sinus blood of dogs, ${ }^{9}$ and digoxin in the usual clinical doses reduces red blood cell potassium. ${ }^{1011}$

When used in therapeutic doses, triamterene, a non-steroidal, potassium-retaining diuretic, increases serum potassium levels in man and reduces urinary potassium excretion. ${ }^{12-14}$ Possibly such a drug could also lead to a rise in intracellular potassium. This would be particularly valuable in pat $i$ ents on digitalis and those undergoing open-heart surgery, as prolonged cardiopulmonary bypass may be associated with a fall in myocardial potassium of up to $50^{\circ},{ }^{15}$ which has been causally related to the development of cardiac arrhythmias. ${ }^{16}$

We have measured the leucocyte sodium and potassium 